\title{
Elżbieta Nieroba
}

Instytut Nauk Pedagogicznych, Katedra Nauk Socjologicznych

i Pracy Socjalnej, Uniwersytet Opolski

\section{Język ma znaczenie. Ramowanie komunikatu w narracji muzealnej}

Pojawienie się kilka dekad temu w sferze publicznej debaty na temat zmian klimatycznych zbiegło się z innymi ważnymi procesami. Po pierwsze, muzea rozpoczęły transformację z instytucji autorytarnych w stronę placówek bardziej demokratycznych [Jones et al. 2020]. Po drugie, nastąpiła era postprawdy [D`Ancona 2018] i zaczęto podważać autorytet nauki, czego przykładem może być działalność A. Wakefielda, a następnie ruchu antyszczepionkowców [Deer 2020]. Problematyka zmian klimatycznych zostało bardzo upolityczniona, w efekcie czego muzea mają trudności z zaprezentowaniem tego zagadnienia w przestrzeni wystawienniczej z perspektywy neutralnej. Tymczasem badania pokazują, że instytucje edukacji niepublicznej, takie jak muzea, cieszą się zaufaniem społecznym [Cameron et al. 2013, Cameron 2015: 53, Salazar 2011, McGhie 2019, Janes, Sandell 2019: 5]. Obowiązkiem muzeum jest zatem próba przełożenia skomplikowanych kwestii naukowych na język dostępny publiczności, zaprojektowanie nowej narracji o świecie i jego przyszłości razem ze swoimi społecznościami. W nowej opowieści powinno się znaleźć miejsce nie tylko dla przodków i dla nas, ale głównie dla przyszłych pokoleń, ponieważ skutki zmian klimatycznych już są z nami. 
Język badaczy z zakresu nauk o Ziemi bardzo różni się od naszego języka codziennego. Wykresy, tabele i statystyki zastępujemy opowieściami, metaforami, anegdotami. Dodatkowo codzienne narracje są „ramowane” przez kontekst, a więc nigdy nie są neutralne [Corner, Clarke 2017: 52]. Opowiadając historię, narrator może wybierać spośród wielu interpretacji i aby być pewnym, że wywrze wpływ na słuchaczy, wybiera taką, która będzie najbliższa ich głęboko zakorzenionym wartościom i światopoglądom [Nisbet 2010: 46]. Ramowanie komunikatu polega wyborze i podkreśleniu określonych aspektów rzeczywistości, przy jednoczesnym nieakcentowaniu lub przemilczeniu innych. Przekaz będzie efektywny jeśli rama będzie istotna dla grupy docelowej, a więc bliska ich schematom interpretacyjnym nabytym w ramach socjalizacji (w przeciwnym razie komunikat zostanie niezauważony). Tak skonstruowany komunikat wskazuje ważne dla określonej grupy odbiorców informacje i pobudzi do działania, ponieważ „Ramy to interpretacyjne fabuły, które wprawiają w ruch określony tok myślenia, komunikując dlaczego dana kwestia może być problemem, kto lub co może być za nią odpowiedzialny i co należy z tym zrobić” [Nisbet 2009: 15].

Muzea mają wszelkie zasoby, aby konstruować narrację, która będzie alternatywą dla tych prezentowanych w mediach i przez polityków, narrację skoncentrowaną na pozytywnej i inkluzywnej przyszłości wypracowaną wspólnie ze swoją publicznością [McGhie 2019: 13]. Badania pokazują, że wywoływanie wśród odbiorców strachu i lęku przed przyszłością nie pobudzają do działania, stanowią zagrożenie dla poczucia własnej wartości [Dickinson et al. 2013]. Rozpoczynanie rozmowy na warunkach, które odpowiadają odbiorcom stanowi pierwszy krok do zaangażowania [Corner, Clarke 2017: 60]. Komunikowanie o klimacie wymaga również nowego podejścia do organizacji, obowiązującej w niej hierarchii, współpracy z innymi podmiotami - zdaniem badaczy muzea muszą nauczyć się poza obowiązującymi granicami fizycznymi i konceptualnymi, powinny być otwarte na przyjmowanie nowych publiczności i przestrzeniami do prowadzenia debat, aby pobudzać aktywność obywatelską [Cameron et al. 2013].

\section{Jak opowiadać o zmianach klimatu. Przykład Muzeum Wody z Londynu}

Zdaniem D. A. Snowa i R. D. Benforda [2000: 619-622] efektywna rama to taka, która jest nośna. Kluczowe znaczenie mają tutaj dwa wzajemnie na siebie oddziałujące wymiary ramy - wiarygodność oraz względna istotność. Na wiarygodność ramy składają się trzy czynniki - spójność 
ramy, wiarygodność empiryczna oraz wiarygodność jej protagonistów i adwokatów. Natomiast względna istotność ramy, czyli nośność idei oraz jej potencjał mobilizacyjny, zależy od takich cech, jak centralność, współmierność doświadczeń oraz wierność narracyjna. Na przykładzie londyńskiego Muzeum Wody przedstawię, jak te wskazówki teoretyczne można wpleść w strategię działania instytucji muzealnej.

Muzeum Wody powstało w 2013 roku w ramach obchodów dwusetnej rocznicy urodzin Johna Snowa - lekarza, który w 1854 roku odkrył źródło epidemii cholery w londyńskim Soho. Jest to muzeum wędrowne, które ze swoimi zbiorami i programami edukacyjnymi przemierzyło już Wielką Brytanię, część Europy, Australię. Sytuacja pandemiczna wymusiła jednak zmianę w sposobie działania muzeum i wizyta w Kanadzie miała charakter wirtualny. Niespodziewanie Muzeum stało się świadkiem wydarzeń, w których nadmiar wody lub jej brak miały dotkliwe znaczenie dla mieszkańców odwiedzanych regionów, świadkiem przeistoczenia się Morza Śródziemnego w cmentarz ciał uchodźców, którzy uciekali przed wojną i suszą w Syrii. Lata działalności Muzeum to także nasilenie dyskusje poświęconych globalnemu zarządzaniu wodą i prawom do wody oraz historyczny moment rozpoczęcia przyznawania rzekom praw człowieka ${ }^{1}$.

Głównym zamierzeniem Muzeum Wody jest skłonienie nas do bliższego przyjrzenia się wodzie, znaczeniom jakie jej nadajemy w codziennych praktykach, jej wpływowi na jakość naszego życia, zarówno w sensie biologicznym, jak i metafizycznym. Świadome zauważenie wody ma nam pomóc przyjąć wobec niej rolę kustosza. Misją Muzeum jest także wyposażenie nas w wiedzę umożliwiającą aktywny udział w debatach, które prawdopodobnie zdominują XXI wiek - dotyczące dostępu, własności i opieki nad wodą. Wiedza na temat znaczenia wody w naszym życiu i jej roli w zmianie klimatu jest również niezbędna, by dbać o dobrostan ludzi i planety [Sharrocks 2019].

Jakich metafor, przykładów, artefaktów użyć, aby opowiedzieć przyszłość wody w epoce antropocenu? Słowa, które dotychczas objaśniały rzeczywistość stały się niewystarczające, aby objąć zmianę wykraczającą poza nasze całe ludzkie doświadczenie:

\footnotetext{
${ }^{1}$ https://museumofwater.co.uk/water-museum-collection/luminato-digital-festival-2020toronto; dostęp 28.07.2021 https://museumofwater.co.uk/water-museum; dostęp 28.07.2021 https://e360.yale.edu/features/should-rivers-have-rights-a-growing-movement-says-itsabout-time; dostęp 28.07.2021
} 
„W ciągu najbliższych stu lat natura wód na Ziemi zmieni się zupełnie. Większość lodowców poza biegunami stopnieje, powierzchnie wód i oceanów podniosą się, temperatura na ziemi wzrośnie, a towarzyszyć temu będą susze lub powodzie, kwasowość mórz wzrośnie w stopniu największym od pięćdziesięciu milionów lat. Wszystkie te zmiany nastąpią w okresie życia dziecka, które urodzi się dziś” [Magnason 2020: 7].

Muzeum Wody wybrało sposób opowieści bardzo intymny — zaprasza do zbierania, ważnej dla nas z jakiś powodów, wody i podzielenia się swoją prywatną historią. W ten sposób wędrowna instytucja jest nie tylko muzeum, ale i żywym, ciągle zmieniającym się dziełem sztuki, na kształt którego wpływ mają odwiedzający — traktowani nie jako publiczność muzealna, ale darczyńcy i kuratorzy niezwykłego spektaklu o wodzie. Wiarygodność tej narracji zależy od 3 czynników — spójności, wiarygodności empirycznej oraz zaufania do autorów.

Spójność oznacza brak rozbieżności pomiędzy deklarowanymi wartościami i założeniami na temat wody, a proponowanymi sposobami działania [Snow, Benford 2000: 620]. Misją Muzeum jest roztoczenie opieki nad wodą przez „zwykłych” obywateli w dobie kryzysu klimatycznego. Dlatego działania skupione są wokół zachęcania do dzielenia się ważnymi opowieściami o wodzie i budowania odpowiedzialności za zasoby wody. Muzeum wędruje po świecie, aby trafić ze swoim przekazem do jak największej liczby kuratorów społecznych. Decyzja o takim sposobie działalności Muzeum wynikała ze świadomości, że dostęp do instytucji kultury wiąże się z wieloma barierami. Dostęp do muzeum należy rozpatrywać w wymiarze fizycznym (odległość od placówki), ekonomicznym (koszt podróży i biletu), jak i intelektualnym (poziom kapitału kulturowego) oraz emocjonalnym (muzeum jako instytucja prestiżowa i elitarna). Poprzez swój nomadyczny charakter Muzeum Wody par excellence otwiera się na każdą historię i włącza każdy głos w dyskusję. Uważnie kolekcjonuje opowieści z różnych społeczności i kultur, prezentujących różnorodną optykę filozoficzną i estetyczną. Muzeum jest obecne na ulicach, festiwalach, rynkach, brzegach rzek, w szkołach, domach starców, centrach handlowych, w miastach i wsiach [Sharrocks 2019: 482]. Inkluzywny charakter placówki podkreśla także bezpłatny udział w programach muzealnych. Jest to gest skierowany przeciwko obowiązującej zasadzie spieniężania każdej idei i każdego zasobu — jednocześnie jest to pytanie o cenę wody, naszego 
wspólnego dobra. Bezpłatne wejście podkreśla także wartość ekonomii dzielenia się [Sharrocks 2019: 484].

Specyficzny charakter działalności Muzeum Wody — w ciągłej podróży — przekłada się na dwie kwestie - stałą siedzibę Muzeum oraz jego pracę z kolekcją. Jest to podjęcie swego rodzaju dyskusji z „tradycyjnym”, czyli stacjonarnym muzeum, którego sercem jest zgromadzenie niepowtarzalnej kolekcji oraz jej ochrona. Wytwarzanie wiedzy jest wówczas rezultatem badań nad kolekcją ekspertów muzealnych w kontekście historycznym, kulturalnym. Pojedyncze elementy informacji zostają powiązane w spójny system poprzez zbudowanie systemu klasyfikacji do zarządzania kolekcją lub przyjęcie konkretnego sposobu interpretacji obiektów [MacDonald i Alsford 1991]. Tymczasem Muzeum Wody opiera swoją reputację na kolekcji budowanej przez obywateli, nie narzuca również „właściwej” interpretacji zbiorów. Oddolnie zbudowana kolekcja ma dodatkowo ulotny charakter. Woda z czasem wyparuje. Pojawia się zatem pytanie, w jaki sposób przechowywać tak efemeryczne fenomeny, jak woda i nasze doświadczenia [Sharrocks 2019: 482]? A także - czy wizytówką muzeum musi być jego budynek?

Architektura muzealna to w przeważającej części imponujące budowle mające potwierdzić wysoki status samej instytucji oraz wartość zgromadzonej kolekcji, ale niekoniecznie stwarzające wrażenie dostępności dla szerokiej publiczności. Wzrost politycznej i społecznej władzy mieszczaństwa w XVIII i XIX wieku ucieleśniała architektura muzeów, nie przypadkowo naśladująca klasyczną doskonałość antycznych monumentów. Siła wyrazu rzymskiej architektury była wykorzystywana w budynkach publicznych od czasów renesansu jako symbol prestiżu władzy — budynki muzealne zapożyczały jońskie kolumnady, monumentalne klatki schodowe, amfiladowe sale ${ }^{2}$. Ulokowane w centrach miast europejskich lub jako część kompleksu miejskich parków w Stanach Zjednoczonych stawały się reifikacją państwa oraz utożsamiały autorytet państwa z ideą cywilizacji. Obecnie sukcesy frekwencyjne biją muzea nie tylko organizujące spektakularne wydarzenia, blockbustery, ale i o imponującej architekturze. Bruno S. Frey określił te mianem superstar museums [Frey, Meier 2006: 410]. Są to muzea rozpoznawalne na całym świecie - posiadają w swoich kolekcjach społecznie pożądane, modne dzieła sztuki i mieszczą się w atrakcyjnie zaprojektowanych budynkach, które same w sobie są dziełami sztuki.

\footnotetext{
${ }^{2}$ Przykład stanowią: Altes Museum w Berlinie autorstwa Karla Friedricha Schinkela, 1825-1828; British Museum w Londynie autorstwa Roberta Smirke`a, 1823-1846.
} 
Usytuowanie ich w atrakcyjnych turystycznie miejscach powoduje, że stają się must see dla turysty odwiedzającego daną okolicę, a tym samym przyczyniają się do rozwoju lokalnych i regionalnych gospodarek. Ich wpływ na „zwykłe” muzea - jak zauważa Monika Murzyn-Kupisz — nie jest jednoznaczny. Z jednej strony są to instytucje postrzegane jako innowacyjne i reformatorskie w świecie muzealnym, których działania są później naśladowane w muzeach działających na mniejszą skalę. Dzięki ogromnemu zainteresowaniu jakie superstar museums budzą wśród turystów są także rzecznikami muzeów en bloc, budując ich pozytywny wizerunek na świecie. Z drugiej jednak strony tworzą nierealistyczne oczekiwania względem potencjalnych zysków finansowych i poziomu frekwencji [Murzyn-Kupisz 2016: 67-68]. Te niezwykle kosztowne projekty, które Robert J. Janes i Richard Sandell określają mianem „architektury próżności” czy „architektury zarozumiałości”, jedynie sprawiają wrażenie nowoczesności i postępu, a tak naprawdę odwracają naszą uwagę od wymagań długoterminowego zrównoważonego rozwoju [Janes, Sandell 2019: 9]. Budynki te są także symbolem mitu, że wszelkiego rodzaju wzrost (czy powierzchni budynku, czy liczby gości) jest symbolem sukcesu. Janes i Sandell postulują, by zarządzający muzeami - nie czekając na polityczne czy naukowe rozwiązania związane ze zmniejszeniem zużycia i emisji gazów cieplarnianych — świadomie postawili na ekonomię postwzrostu, która szanuje ograniczenia natury i odchodzi od nadmiarowej konsumpcji [Janes, Sandell 2019: 10].

Kolejnym czynnikiem wpływającym na wiarygodność przekazu jest jego wiarygodność empiryczna, czyli umiejętność wskazania wskaźników twierdzeń na temat problematyzowanego zagadnienia. Kluczowe jest tutaj założenie, że wskaźniki te mają być odczytywane jako „prawdziwe” przez grupę, do której kierowany jest komunikat. Wiarygodność empiryczna jest zatem tym większa, im większa umiejętność autorów przekazu dopasowania się do sposobów postrzegania i oceniania rzeczywistości grupy docelowej [Snow, Benford 2000: 620]. W przypadku Muzeum Wody empirycznie zweryfikowanych dowodów na zachodzące zmiany klimatu dostarcza nauka. Jednak język naukowy zostaje przetłumaczony na opowieści bliskie odwiedzającym.

Kolekcję Muzeum stanowią butelki z wodą podarowane przez odwiedzających. Jest to odpowiedź na pytanie, które stawia Muzeum - jeśli mógłbyś_abyś zatrzymać jedną wodę, co to byłaby za woda? Muzeum 
zatem zmusza nas do poświęcenia chociaż kilku chwil na zastanowienia się, jaką rolę w naszym życiu pełni woda i co w niej najbardziej cenimy. I w tym momencie rodzi się kolekcja muzealna złożona nie tylko z butelek z wodą, ale także z niepowtarzalnych opowieści. Każda podarowana butelka traktowana jest z należytym jej szacunkiem — jak wartościowy obiekt muzealny. Na tyle wartościowy, że nie podlega „ulepszeniu” przez profesjonalnych kuratorów, ponieważ w Muzeum Wody przyjęto zasadę, że każdy darczyńca jest kuratorem i ekspertem. To na darczyńcy spoczywa odpowiedzialność, co zostanie upamiętnione w Muzeum. Bez jego obecności i zaangażowania Muzeum przestanie istnieć - to oficjalna deklaracja współzależności. W ten sposób Muzeum wprost pokazuje, że odcina się postrzegania instytucji muzealnej jako skarbnicy dziedzictwa narodowego. Kolekcjonuje indywidualne doświadczenia oddolnych kuratorów nie bacząc na granice narodowe. Muzeum Wody wyznacza nową filozofię relacji między instytucją a odwiedzającymi [Sharrocks 2019: 483]. Muzeum nie eksponuje jedynie kolekcji, ale buduje platformę do wspólnej pracy nad generowaniem znaczeń i sensów wody w kulturze. Muzeum nie dostarcza jednej interpretacji, ale wspiera budowanie sieci narracji o wodzie. Łączy ludzi z różnych środowisk, wspomaga prowadzenie dialogu.

Ostatnim elementem mającym wpływ na wiarygodność przekazu jest postrzegana wiarygodność autorów komunikatu. Wiarygodni autorzy wydają się bardziej przekonujący [Snow, Benford 2000: 620-621]. Muzeum jako instytucja kultury cieszy się zaufaniem społecznym. Badania pokazują również, że respondenci oczekują podejmowania przez muzea trudnych tematów oraz zajmowania stanowiska w palących kwestiach społecznych. Zaangażowanie muzeum sprawiłoby również, że stałoby się ono placówką istotną dla obywateli, bliższą ich codziennemu życiu i problemów, z którymi się borykają [Lyons, Bosworth 2019: 177]. Tymczasem wiele muzeów amerykańskich, jak wynika z wywiadów zrealizowanych z ekspertami muzealnymi, stroni od eksponowania tematu zmian klimatycznych z dwóch głównych powodów. Są to po pierwsze kwestie typowo praktyczne i logistyczne - zagadnienie jest bardzo złożone i trudno go zaprezentować odwiedzającym w przystępny, a jednocześnie nieupraszczający sposób, dodatkowo nauka wciąż prezentuje nowe ustalenia, za czym nie nadąża produkcja wystaw. Druga kwestia związana jest z unikaniem kontrowersji, gdyż temat zmian klimatycznych stał się problemem bardzo upolitycznionym, muzea są też często sponsorowane przez koncerny 
naftowe [Kuchmentthe 2014]. Na przykład Houston Museum of Natural Sciences z obawy przed negatywną reakcją publiczności nie podejmowało tematu antropogenicznych powodów zmian klimatycznych. W ten sposób Muzeum pokazało, że nie dba o tych, którzy ponosili największe koszty w związku z działalnością rafinerii, a więc robotników mieszkających w jej pobliżu [Lyons, Bosworth 2019: 177]. W 2008 roku, w ramach projektowania nowej galerii poświęconej zmianom klimatu, Science Museum w Londynie przeprowadziło szeroko zakrojone badania docelowej publiczności. Badania wykazały m.in. że respondenci najbardziej ufają komunikatom konstruowanym przez naukowców, organizacje pozarządowe oraz muzea. Wyodrębniono również trzy czynniki wpływające na poziom zaufania do źródeł informacji. Respondenci byli szczególnie wyczuleni na: hipokryzję (autorzy komunikatu sami powinni stosować zalecane przez siebie aktywności związane z przeciwdziałaniem zmian klimatycznych), zysk (autorzy komunikatu nie powinni osiągać żadnych korzyści finansowych) oraz niespójność (autorzy komunikatu powinni mieć ugruntowane stanowisko w danej sprawie) [Dillon, Hobson 2013: 216-222].

Poza wiarygodnością na efektywność wybranej ramy komunikatu wpływ ma jej względna istotność w ocenie odbiorców, na którą składają się centralność, współmierność doświadczeń oraz wierność narracyjna. Pierwszy wymiar - centralność - mówi o tym, w jakim stopniu odbiorcy komunikatu identyfikują się z głoszonymi przekonaniami, wartościami i ideami. Im większa ich zgodność, tym większa szansa podjęcia działania [Snow, Benford 2000: 621]. Muzeum Wody jest nastawione na teraźniejsze doświadczenie darczyńców. Pracownicy Muzeum opiekują się zbiorami, ale i darczyńcami. Uważnie słuchają głosu każdej osoby. Za zgodą zwiedzających rozmowy są nagrywane, ponieważ ważna jest każda historia. To, co dzisiaj czujemy, w co wierzymy. Każda narracja jest warta zapamiętania w dźwiękowym archiwum Muzeum. Butelkom jest nadawany numer, a darczyńcy własnoręcznie przygotowują jej etykietę, kreśląc kilka słów o historii związanych z tą konkretną wodą [Sharrocks 2019: 483].

Współmierność doświadczeń to kolejna cecha, która wpływa na istotności ramy. Związana jest ona z dopasowaniem przekazu nadawcy do sensów i znaczeń, jakie swojemu życiu codziennemu nadają odbiorcy. Im większe dopasowanie, tym większa szansa podjęcia działania [Snow, Benford 2000: 621]. Wykorzystanie na wystawie codziennego języka, znanych idei i symboli stwarza platformę eksplorowania i poszukiwania rozwiązań dla problemów 
bliskich nam, jak i tych występujących w dalekich częściach świata. Jeśli zachodzi współmierność doświadczeń odwiedzający ma okazję nawiązać osobiście znaczącą relację z innymi i szerzej - z naturą. Odnalezienie siebie w tej relacji jest szansą na podjęcie wyzwań, które będą miary charakter osobiście znaczący, co będzie dowodem na realny wpływ doświadczenia muzealnego na życie codzienne. Relacja zawsze obarczona jest różnorodnymi emocjami, dzięki którym przeżywane doświadczenie jest bogatsze i pełniejsze. W muzeum opowiadającym o zmianie klimatu towarzyszyć nam mogą emocje smutku czy strachu, ale także radości i zaufania, gdy poszukujemy rozwiązań i planujemy przyszłość. Dlatego też wystawa w Muzeum Wody to wystawa zwykłych, a jednocześnie wyjątkowych codziennych chwil - które opowiadają o dobrych i złych momentach w życiu darczyńców. Historie dołączone do podarowanej wody mogą wywoływać w nas zarówno uśmiech, jak i pogrążać w głębokim smutku. Oto przykładowe obiekty z kolekcji Muzeum: magiczny eliksir od 8-letnich chłopców, łzy radości mężczyzny, który dowiedział się, że został wyświęcony na księdza, woda z przeciekającego dachu, wspomnienie wody z wyschniętego kanału w Iranie, letni deszcz, błotnista kałuża, woda z pierwszej lekcji pływania dziecka, śnieżki od trzylatka, woda od uchodźców z całego świata, woda z Morza Śródziemnego. Dzięki opowieściom darczyńców organizatorzy Muzeum dowiedzieli się, jak zmieniające się piaszczyste dno rzeki wpływa na życie okolicznych mieszkańców, poznali najlepsze miejsca do łowienia makreli, poznali sposoby nawadniania ogrodów botanicznych, a nawet zapoznali się z kąpielowymi zwyczajami w wiktoriańskiej Anglii [Sharrocks 2019: 485-487].

Wierność narracyjna lub rezonans kulturowy to ostatni element względnej istotności ramy, który wpływa na jej efektywność. Wierność narracyjna polega na dopasowaniu przekazu komunikatu do opowieści, symboli i mitów odbiorców [Snow, Benford 2000: 622]. Aby odnieść sukces w komunikowaniu o zmianach klimatu niezbędnym wydaje się konstruowanie nowych metafor, które pozwolą ludziom zrozumieć złożone zjawiska, wyobrazić nowe sytuacje, ale jednocześnie będą w jakimś stopniu odnosić się do znanego im systemu znaczeń [Dickinson et al. 2013]. W Muzeum Wody kolekcja rozwija się w ścisłej współpracy z lokalną społecznością. Muzealnicy dostrzegają i upamiętniają historię regionu i jego specyficzną relację z wodą. Muzeum każdorazowo angażuje się w lokalne problemy związane $\mathrm{z}$ wodą lub jej brakiem. Na przykład podczas pracy w jednej z dzielnic 
Rotterdamu, w której mówi się ponad 143 językami, podejmowano temat strachu przed wodą (znaczna część miasta leży poniżej wód gruntowych), jak urbanistyka radzi sobie z wodą, dyskutowano o prawie wodnym oraz o starożytnej praktyce polderowania (osuszania). Co ciekawe holenderski czasownik - polderować - oznacza także debatowanie, nieustanne negocjacje z zainteresowanymi stronami, do momentu stworzenia wspólnego stanowiska [Sharrocks 2019: 485].

W obliczu zmian klimatu możemy oceniać instytucje publiczne na podstawie ich zaangażowania w proces zmian społecznych, które są niezbędne dla działań mitygacyjnych i adaptacyjnych. Muzea mają wyjątkową pozycję, ponieważ jako placówki gromadzące historie i dzielące się wiedzą, w których wiele osób szuka wskazówek i inspiracji, mogą wspólnie z nimi budować obraz pożądanej przyszłości. A to pierwszy krok w jej realizacji. Muzea są dobrze przygotowane do celowego angażowania publiczności-stereotypowo przypisuje im się rolę zaufanych przewodników. Ale muzeum nie jest jedyną instytucją odpowiedzialną za edukację obywateli. Nie każde muzeum musi przygotowywać wystawę dedykowaną bezpośrednio zmianom klimatycznym, jak nietypowe, bo wędrowne i bez stałej siedziby, Muzeum Wody. Chociaż korzystając z dostępnych zasobów, placówki muzealne - bez względu na rodzaj kolekcji, czy miejsce swojej działalności - mogą swoimi codziennymi wyborami pokazywać, że kwestie klimatyczne nie są im obojętne.

Przywołane w tekście Muzeum Wody nie stanowi idealnego wzoru do naśladowania przez inne instytucje z wielu powodów (związanych z kolekcją, przewodnim tematem czy sposobem działania) — ale może być inspiracją do podjęcia małych kroków w stronę bardziej świadomego mierzenia się z globalnym problemem. Pokazuje, jak słuchać publiczności, w jaki sposób negocjować ich nową pozycję w działalności muzeów, jak nawiązywać relacje z różnymi społecznościami, jak wspólnie z nimi pracować nad wspólną przyszłością. Analizowane cechy efektywności przedstawionych w danej ramie interpretacyjnej komunikatów pokazują, że czasami drobne zmiany w relacji z publicznością, większe otwarcie na nią dają szanse na zbudowanie aktywnej i zaangażowanej społeczności.

Liczy się każde słowo i każdy gest. Nie ma planety B. 


\section{Bibliografia}

\section{Benford Robert D., Snow David}

2000: Framing Processes and Social Movements: An Overview and Assessment, "Annual Review of Sociology”, t. 26.

\section{Cameron Fiona}

2015: We Are on Nuture`s Side? Experimental Work in Rewriting Narratives of Climate Change for Museum Exhibitions w: Climate Change and Museum Futures, red. F. Cameron, B. Neilson, Nowy Jork, Londyn: Routledge.

\section{Cameron Fiona, Hodge Bob, Salazar Juan F.}

2013: Representing climate change in museum space and place, „WIREs Climate Change” nr 4.

\section{Corner Adam, Clarke Jamie}

2017: Talking Climate. From Research to Practice in Public Engagement, Cham: Palgrave Macmillan.

\section{D`Ancona Matthew}

2018: Postprawda, przeł. Michał Sutowski, Warszawa: Wydawnictwo Krytyki Politycznej.

\section{Deer Brian}

2020: Wojna o szczepionki. Jak doktor Wakefield oszukał świat, przeł. Katarzyna Bażyńska-Chojnacka, Piotr Chojnacki, Poznań: Wydawnictwo Poznańskie.

\section{Dickinson Janis, Crain Rhiannon, Yalowitz Steve, Cherry Tammy}

2013: How Framing Climate Change Influences Citizen Scientists'Intentions to Do Something About It, w: "The Journal of Environmental Education”, 44:3.

\section{Dillon Justin, Hobson Marie}

2013: Communicating global climate change: issues and dilemas, $\mathrm{w}$ : Communication and engagement with science and technology: issues and dilemas, red. J.K. Gilbert, S. Stocklmayer, Londyn: Routledge.

\section{Frey Bruno S., Meier Stephan}

2006: Cultural economics w: A Companion to museum studies, red. S. Macdonald, Oxford: Blackwell Publishing.

\section{Janes Robert R., Sandell Richard}

2019: Posterity has arrived. The necessary emergence of museum activism, w: Museum Activism, red. Robert R. Janes, Richard Sandell, Nowy Jork: Routledge.

\section{Jones Rose, Hussain Nazia, Spiewak Mike}

2020: The Critical Role Research and Evaluation Assume in the Posttruth Era of Climate Change, "Journal of Museum Education”, 45:1.

\section{Kuchmentthe Anna}

2014: Museums tiptoe around climate change, "Dallas Morning News”, 10.06.2014, https:// www.dallasnews.com/news/2014/06/15/museums-tiptoe-around-climate-change/; dostęp 15.07.2021.

\section{Lyons Steve, Bosworth Kai}

2019: Museums in the Climate Emergency, w: Museum Activism, red. Robert R. Janes, Richard Sandell, Nowy Jork: Routledge. 


\section{MacDonald George F., Alsford Stephen}

1991: The Museum as Information Utility, “Museum Management and Curatorship”, nr 10.

\section{Magnason Andri}

2020: O czasie i wodzie, przeł. J. Godek, Kraków: Wydawnictwo Karakter.

\section{McGhie Henry}

2019: Climate Change Engagement: A Different narrative w: Addressing the Challenges in Communicating Climate Change Across Various Audiences, red. W.L. Filho, B. Lackner, H. McGhie, Hamburg, Gratz, Manchester: Springer.

\section{Murzyn-Kupisz Monika}

2016: Instytucje muzealne z perspektywy ekonomii kultury, współpraca Jarosław Działek, Kraków: Universitas.

\section{Nisbet Matthew}

2009: Communicating Climate Change: Why Frames Matter for Public Engagement, „Environment: Science and Policy for Sustainable Development”, 51:2.

\section{Nisbet Matthew}

2010: Knowledge Into Action: Framing the Debates Over Climate Change and Poverty, w: Doing News Framing Analysis. Empirical and Theoretical Perspectives, red. Paul D`Angelo, Jim Kuypers, Nowy Jork, Londyn: Routledge.

\section{Salazar Juan F.}

2011: The Mediations of climate change: museums as citizens’ media, „Museum and Society" nr 9(2).

\section{Sharrocks Amy}

2019: Treasuring Evaporation: The Radical Challenge of a Museum of Water, w: Addressing the Challenges in Communicating Climate Change Across Various Audiences, red. W. L. Filho, B. Lackner, H. McGhie, Hamburg: Springer.

\section{Elżbieta Nieroba}

\section{Language matters. The structure of the message in museum narration}

The events that we witnessed in the summer of 2021 - downpours and floods in Germany, fires in Turkey, a heatwave in Canada, or the tornado in the Czech Republic - are examples of extreme phenomena that we cannot say do not concern us, because they are happening somewhere else or they affect someone else. The spatial distance that has so far separated us from the effects of climate change is narrowing. The article is an attempt to answer the question of how a museum can structure its message in order to engage the public in mitigation and adaptation activities to prevent climate change. Using the example of the Water Museum in London, I discuss the features of effective communication. Effective communication is one that meets two key characteristics - credibility and relative relevance.

Keywords: Anthropocene Epoch, text structure, communication 